\title{
The Cyrilka Cave-the longest crevice-type cave in Czechia: structural controls, genesis, and age
}

\author{
Jan Lenart ${ }^{*}$, Martin Kašing ${ }^{2}$, Petr Tábořik ${ }^{3,4}$, Natalia Piotrowska ${ }^{5}$, and Jacek Pawlyta ${ }^{5}$ \\ ${ }^{1}$ Department of Physical Geography and Geoecology, University of Ostrava, Chittussiho 10, 71000 Ostrava, Czechia \\ ${ }^{2}$ Department of Geological Engineering, VŠB-Technical University of Ostrava, 17. listopadu 15, 70833 Ostrava-Poruba, Czechia \\ ${ }^{3}$ Institute of Hydrogeology, Engineering Geology and Applied Geophysics, Charles University in Prague, Albertov 6, 12843 Prague, Czechia \\ ${ }^{4}$ Institute of Rock Structure and Mechanics, Czech Academy of Science, V Holešovičkách 94/41, 182 09 Prague, Czechia \\ ${ }^{5}$ Institute of Physics-CSE, Division of Radioisotopes, Silesian University of Technology, Konarskiego 22B, 44-100 Gliwice, Poland
}

\begin{abstract}
The Cyrilka Cave is the second longest pseudokarst cave and the longest crevice-type cave in Czechia. Developed within the headscarp area of a deep-seated landslide, the cave became a focus of scientific research in recent years when new passages were discovered. Structural analysis provided a general tectonic plan of the cave, as well as more detailed data on geometry and kinematics of the relaxed rock massif. The primary structure of NNE- to ENE-striking bedding is broken by a system of NNE-striking fissures interconnected by two continuous ENE-striking dextral fracture zones. Abundant signs of recent sinistral strike-slips within the rock massif represent a bold structural feature of the cave. Along with DEM imaging and a detailed survey of the cave, 2-D and 3-D ERT measurements completed an image of the main predispositions and revealed the internal structure of the slope deformation. These measures also detected unknown crevices above the existing headscarp, which indicate the retrograde evolution of the landslide. Methodologically, we used the 3-D electrical resistivity tomography in the incoherent sedimentary flysch rocks for the first time. Based on radiocarbon dating of the stalactite core, the minimum age of the cave is up to $19,900 \pm 280$ cal BP, which is the oldest age detected in the area of the Outer Flysch Carpathians so far; we thoroughly discuss further indirect evidence indicating a probable Late Pleistocene age of the cave.
\end{abstract}

Keywords: $\quad$ pseudokarst, crevice-type cave, mass movements, radiocarbon dating, Outer Western Carpathians Received 29 May 2018; Revised 28 September 2018; Accepted 2 October 2018

Citation: Lenart J., Kašing M., Tábořík P., Piotrowska N. and Pawlyta J., 2018. The Cyrilka Cavethe longest crevice-type cave in Czechia: structural controls, genesis, and age. International Journal of Speleology, 47 (3), 379-392. Tampa, FL (USA) ISSN 0392-6672

https://doi.org/10.5038/1827-806X.47.3.2210

\section{INTRODUCTION}

The Cyrilka Cave is one of the most famous pseudokarst feature in Czechia. At $552 \mathrm{~m}$ in length, it is the longest crevice-type cave in Czechia according to the classification proposed by Vitek (1983) and the second-longest pseudokarst cave (after the Teplická Cave: 1,065 m). Crevice-type caves belong to the category of caves originated by the gravity disintegration of rocks (Bella \& Gaál, 2013). As Vitek (1983) states, crevice-type caves are mostly produced by the movements of large blocks of compact rock masses arising as cracks (widened along tectonic contacts or bedding planes) and clefts (not of tectonic origin). Margielewski and Urban (2003) consider the crevices to be free space between two rock blocks when at least one of them is affected by slope movement. According to morphogenetic classification (Urban \&
Margielewski, 2013; Margielewski \& Urban, 2017), the cave belongs to the category of intermediate caves.

The Cyrilka Cave has been known for centuries. Due to its specific genesis, morphology and environment, it has attracted the attention of many scientists. The first accurate map of the cave was published in 1953 (Tučník, 1953). Since then, the cave has been extensively studied, extended and mapped. The New Part of the cave was discovered in 1976, increasing the length from 165 to $375 \mathrm{~m}$ (cf Foldyna, 1968 and Wagner et al., 1990). More recent surveys increased the length to $511 \mathrm{~m}$ and depth to $16 \mathrm{~m}$ (Wagner \& Lenart, 2012) and $535 \mathrm{~m}$ in 2013 (Lenart et al., 2013). The scientific studies undertaken include cave microclimates (Wagner et al., 1990; Lenart, 2012), landslide development including the role of groundwater (Baroň \& Kašperáková 2007), the use of the TM-71 optical-mechanical crack gauge (Klimeš et 
al., 2012), geology and hydrochemistry (Malinčíková, $2013,2015)$ and the genesis and evolution of the cave (Lenart et al., 2014).

Although the range of the research is quite extensive, yet problems there unresolved as those related to the tectonic predispositions of the cave genesis, velocity and detailed way of its development as well as the absolute age of the cave.

The main goals of the present study are: (i) to present the results of a new speleological mapping carried out between 2010 and 2013; (ii) to deepen the knowledge about the structural setting of the cave, especially about its structural predisposition, geometry and kinematics; (iii) to reveal the internal structure of the deep-seated landslide (DSL) in the cave site; (iv) to detect possible unknown underground crevices upslope from the cave by the use of electrical resistivity tomography; and (v) to delimit the absolute age of the cave with the help of the radiocarbon dating strategy. The method of the 3-D electrical resistivity tomography is applied for the first time in the incoherent sedimentary flysch rocks.

\section{LOCATION, GEOLOGICAL AND MORPHOLOGICAL SETTING}

The Cyrilka Cave is situated in the north-eastern part of Czechia in the Moravskoslezské Beskydy Mountains (Fig. 1A), which belongs to the Outer Western Carpathians, formed by flysch Mesozoic (Late Jurassic) to Paleogene/Neogene (Early Miocene) sedimentary rocks. During the Lower and Middle Miocene Alpine orogeny phases, these sediments were folded and thrust onto the foredeep in the northern direction, forming several nappes (Menčik et al., 1983). The Cyrilka Cave is situated in the culmination portion of the Silesian Unit flysch nappe on the Radhošt Ridge (Fig. 1A), which is formed by the Godula Formation (Upper Godula beds). The sedimentary strata consist of thick-bedded $(2-4 \mathrm{~m})$ sandstones or conglomerates alternating with very thin-bedded (up to $20 \mathrm{~cm}$ ) claystones or siltstones (Menčik et al., 1983) with glauconitic admixture and clayey-ferrous cement (Malinčíková, 2013). The Radhošt Ridge is important for the appearance of the Pustevny Sandstone, an informal member of the Godula Formation, characterized by thick-bedded green-grey greywacke or arkosic sandstone (Eliáš, 2000). During the Miocene, the rocks were disrupted by joints and faults (Menčik et al., 1983).

Morphologically, the Radhošt Ridge is asymmetric. Because of the slight strata south-east dip $\left(9^{\circ}-35^{\circ}\right)$, the ridge forms an escarpment with the northern short and steep scarp slopes and southern long and gentle dip slopes. The Cyrilka Cave is situated on the eastern slope, which is strongly affected by the development of a frontal complex of DSL, involving spreading, translational and rotational movements (Fig. 1B). This complex affects at least two valleys. There are three main localities with clearly distinguishable topography typical for a DSL. The northern DSL with diffuse headscarp is developed from below the

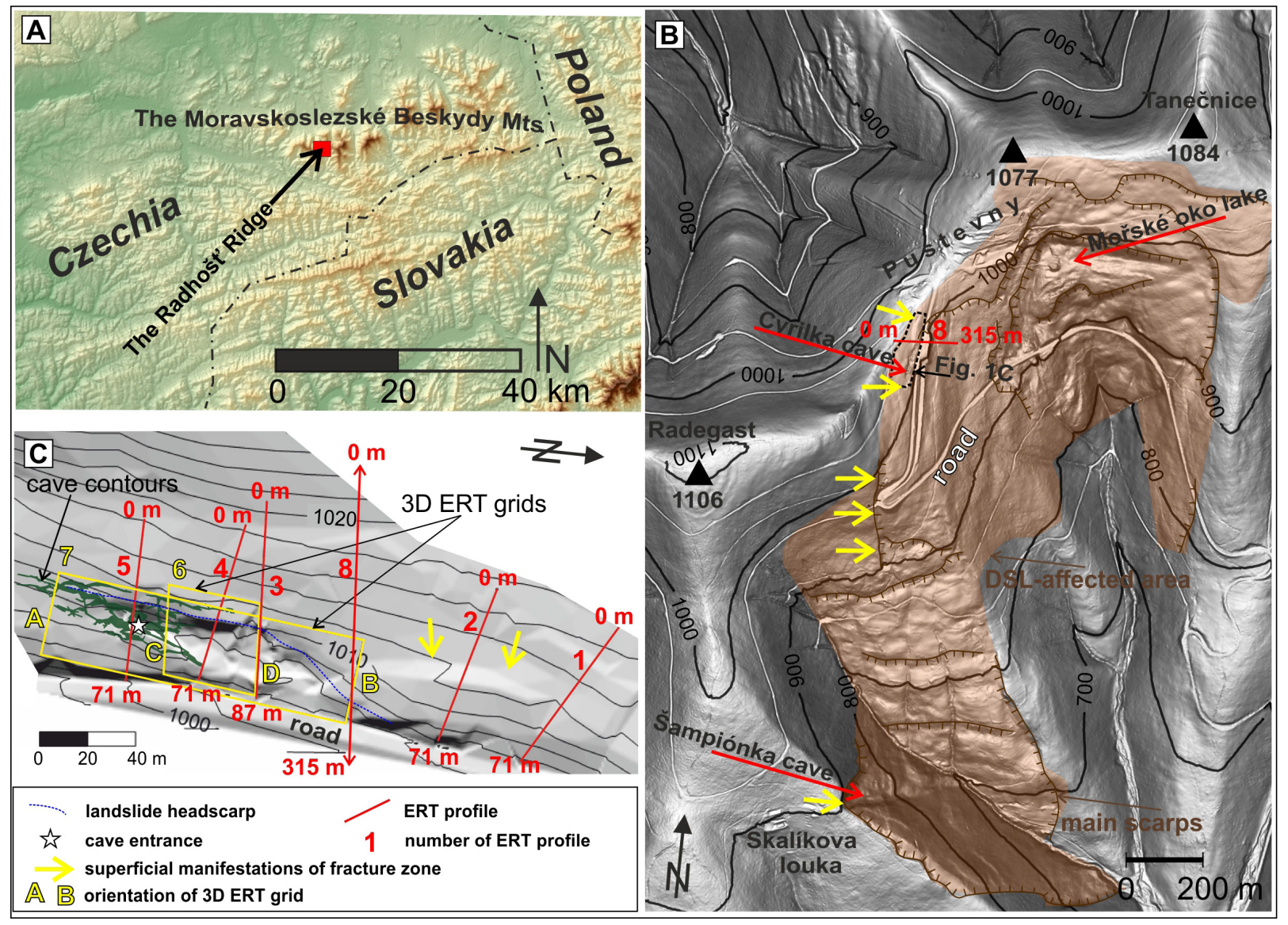

Fig. 1. Regional setting: A) SRTM model of the wider area; B) High-resolution LiDAR-derived Digital Terrain Model of the Czechia provided by the State Administration of Land Surveying and Cadastre (DMR5G) with a spatial resolution of $1 \mathrm{~m}$ and the maximum error in altitude reaching $0.3 \mathrm{~m}$ in forested areas; highlighted area of clear topographic response to gravitational movement;

C) DEM generated from direct topographic measurements with cave contours and measuring lines of ERT profiles. 
unnamed peak $(1,077 \mathrm{~m}$ a.s.1.; Fig. 1B), reaching the bottom of the valley. The side margins are clearly developed in addition to slid blocks in the upper part of the deformation where the Mořské oko landslidedammed lake is formed. According to the clearly visible lineaments on the LIDAR image, the blocks are separated along the NE-SW, NNE-SSW and ESE-WNW directions. The main body is $0.8 \mathrm{~km}$ long as well as wide. Other initial forms of gravitational processes are visible above the headscarp more to the north, and there is a similar situation set up in the western part, where the gravitational trench with the entrance into the Cyrilka Cave occurred. More to the south-west, the complex continues with less visible gravitational forms towards the second distinct DSL, which occupies the left-oriented slopes of an unnamed deeply incised valley. Again, the undulating topography helps to reveal slid rock blocks separating along the N-S, E-W and SE-NW directions. The main body is $0.9 \mathrm{~km}$ long and $0.5 \mathrm{~km}$ wide. The whole complex of gravitationally affected massif terminates in the opposite slope of the same valley where the wedge-shaped rockslide is developed. The slid rock mass below the steep and rocky headscarp includes the Šampiónka crevice-type cave (length: $15 \mathrm{~m}$, depth: $7 \mathrm{~m}$ ).

\section{A BRIEF DESCRIPTION OF THE CYRILKA CAVE}

The Cyrilka Cave is developed mostly below the shallow trench with several pseudokarst sinkholes and rocky depressions filled with debris (WGS84: 49.4861N, 18.2636E).

The Cyrilka is the longest crevice-type cave in Czechia and is $552 \mathrm{~m}$ long and $16 \mathrm{~m}$ deep (Figs. 2 and 3). The cave comprises three morphologically distinguishable levels developed at a shallow depth. The middle level includes more than $90 \%$ of underground passages, which are regularly shaped in geometry-high but narrow, with ceilings formed by lower bedding planes or wedged boulders, and a floor formed by a mixture of debris and clayey mud. The passages are in some places widened into larger chambers.

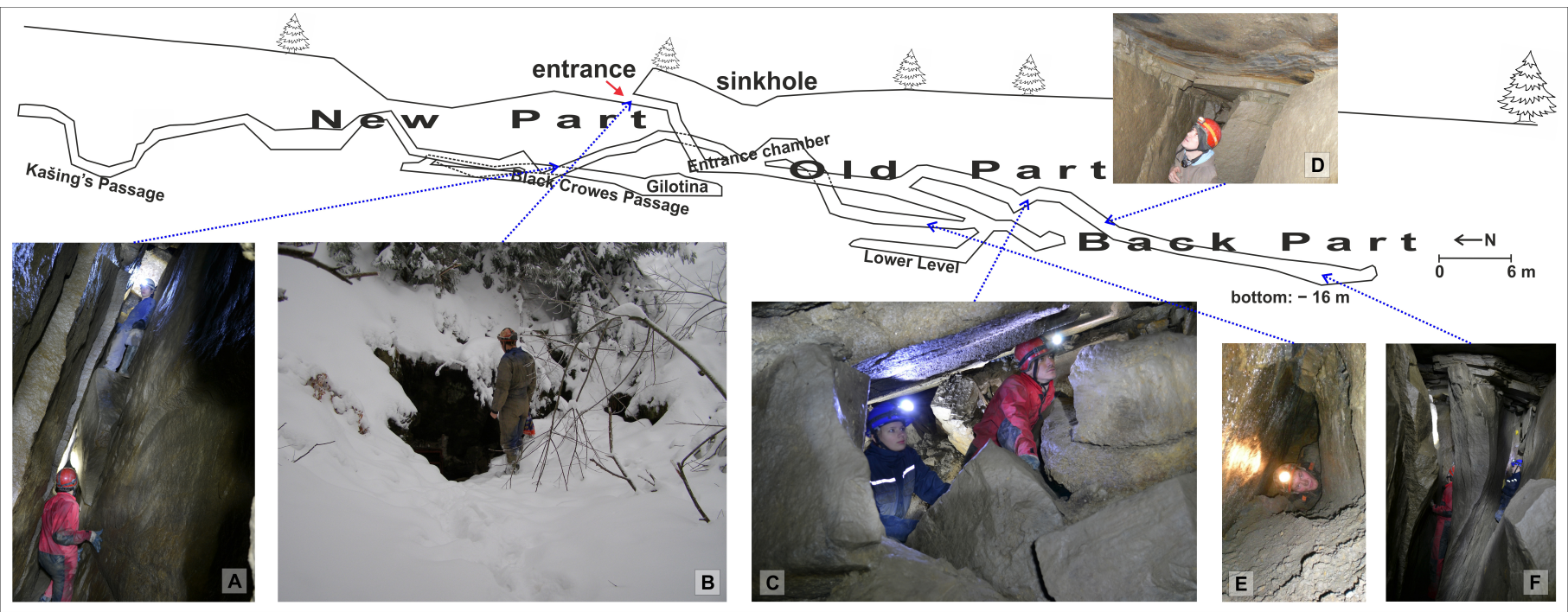

Fig. 2. Longitudinal profile of the Cyrilka Cave: A) Crevice within the New Part; B) Entrance; C) Bedding Chamber; D) Flat undisrupted ceilings formed by sandstone bed; E) Narrow crevices within the Old Part; F) The bottom of the cave. Photos: A, C, D, and F - J. Lenart; B - O. Lenart; E - V. Škarpich.

The majority of the passages follow a NNE-SSW orientation, parallel with the strike of the slope. The only exceptions are two ragged passages following two ENE-WSW fracture zones, which divide the cave into three morphologically and genetically different segments (Fig. 3). Each of them has undergone a different gravitational evolution with different morphological results (see Lenart et al., 2014). The overall horizontal arrangement of the cave system is fan-shaped, with the tip at the southern termination.

The detailed lithology exposed inside the cave is still poorly investigated. The dominant mediumgrained sandstones with clayey-ferrous cement are altered by incoherent and intensively weathered coarse-grained sandstones or even conglomerates in the upper floor of the cave. The clayey-ferrous cement typical for medium-grained sandstones is supplied there by the calcareous cement which fills the larger pores (Malinčiková, 2013). Additionally, according to the analyses by M. Štastný (content of $\mathrm{CaCO}_{3}$ according to the method of Konta, 1967), the calcareous admixture constitutes up to $16 \%$ of the coarse-grained sandstone sample. This composition probably resulted in the formation of small sodastraw-like stalactites in the New Part of the cave. During the mapping of the terminal parts of the cave, we found two other sites with this type of speleothems in similar positions. Such speleothems were also described in lithologically similar crevice-type caves in Poland (Urban et al., 2007a, b) and Slovakia (Imrich et al., 2007; Majerníčková et al., 2005). In contrast, Malinčíková (2015) investigated the possible calcareous precipitation in the Old Part of the cave with negative results. She recognized only dissolution.

\section{METHODS}

\section{Speleological mapping}

The cave was remapped between 2010 and 2013 using a Leica Disto A3 range-finder with a Disto-X component using PocketTopo software and drawn in CorelDRAW. Several passage cross-sections (Fig. 3) 
and a N-S longitudinal profile of the cave (Fig. 2) were constructed. In the most uptodate survey, the overall length of the cave is now $552 \mathrm{~m}$ and the depth is $16 \mathrm{~m}$.

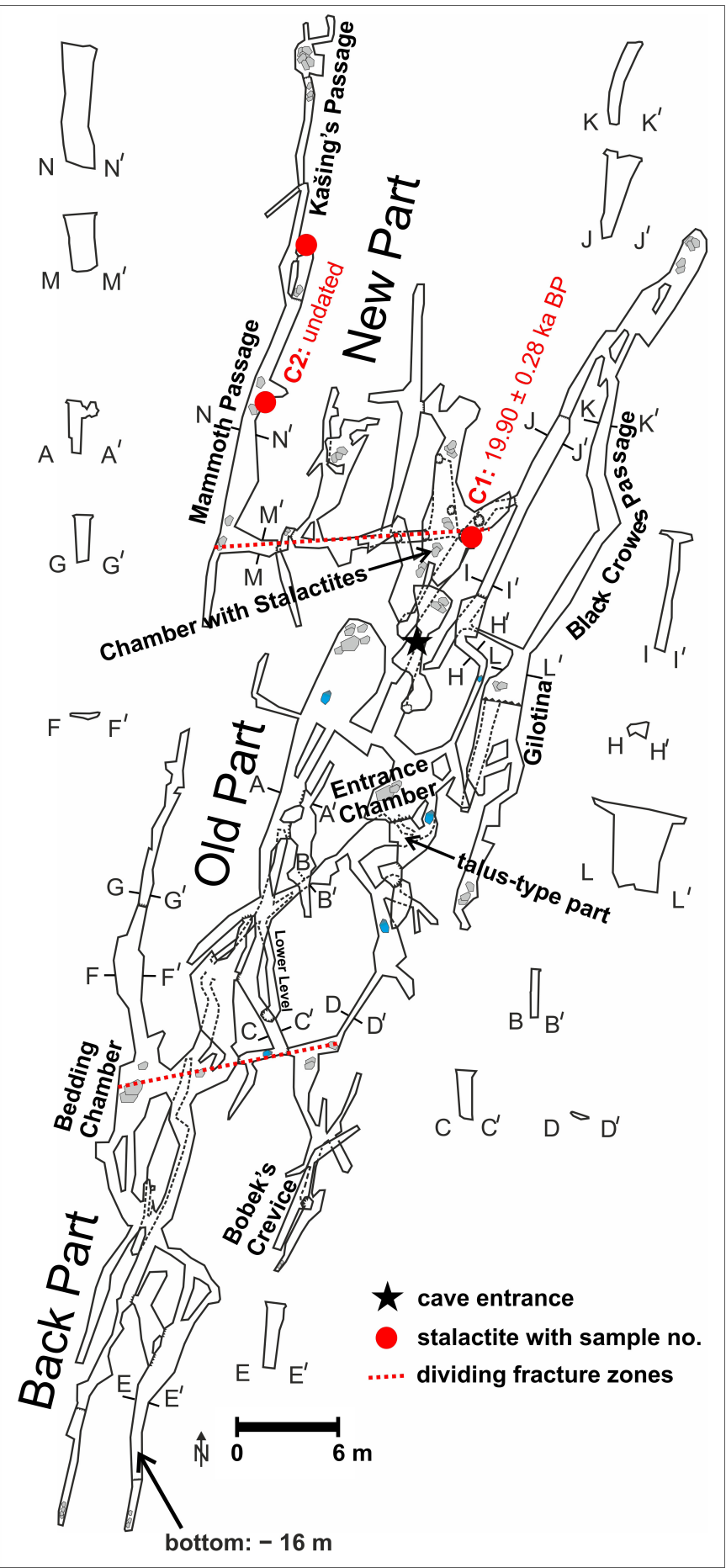

Fig. 3. Recent cave plan by J. Lenart (2012) with cross-sections.

\section{Structural analysis}

Applied structural analysis is mainly based on the geometric data of fractures, faults and bedding and kinematic analysis of fault and fractures in order to assess the cave structural control in terms of genetic interpretation.

Measured in dip direction / dip angle format for planes and trend/plunge format for lines, all structural data have been shown in the lower hemisphere of Lambert equal area projections. Statistical analyses used for the determination of the contour density on projections were adopted from Fisher (1953). During the measurement, the extensional and shear fractures were recorded to explain the structural control and genesis of the cave. The direction of movement was recognized from slickenlines and other features on fault and fracture surfaces. The shear sense of movement was inferred from Riedel shears, tension cracks, other minor fractures, synkinematic quartz fibres and marker offsets (Riedel, 1929; Petit 1987). Due to gravitational deformation and associated rotations of rock blocks within the cave, a dynamic analysis of fault slip data was avoided. The strike expression of all structural features is bi-directional, but we used uni-directional marking for simplification.

\section{Electrical resistivity tomography}

The internal structure of sandstone-dominated flysch rock was investigated by means of electrical resistivity tomography (ERT). The survey was performed in order to: (i) reveal the internal structure of the DSL in the area of the Cyrilka Cave and its vicinity and (ii) find possible unknown underground crevices upslope from the Cyrilka Cave (above the main headscarp) and northwards from the cave near the Pustevny settlement, under a shallow depression.

The ERT is a two- or three-dimensional geophysical technique. Measurements are based on direct current passing through a pair of grounded electrodes to the subsurface, and on measured potentials on a pair of potential electrodes. According to Ohm's Law and the geometric factor ( $\mathrm{k}$-coefficient), the apparent resistivity $\left(\rho_{a}\right)$ is then calculated. The geometric factor is a parametric description of the geometry used for the measurement (electrode array, electrode spacing) (Ward, 1990; Griffiths \& Barker, 1993; Loke \& Barker, 1996; Loke, 1999; Milsom, 2005). With the use of inverse modelling (least square inversion) and other optimizations (finite element modelling, finite difference modelling), resistivity pseudosections are calculated from the apparent resistivity values. The final inverted resistivity models are displayed as tomographic sections (Res2D/3Dinv; Loke, 1999).

For the investigation of the Cyrilka site, both 2-D and 3-D surveys were performed (see the localization of the profiles in Figs. 1B and 1C). A broader area of the dissected ridge was examined by five parallel 2-D ERT profiles of lengths from 71 to $87 \mathrm{~m}$ and $1 \mathrm{~m}$ electrode spacing, by one $315 \mathrm{~m}$ long profile with a $5 \mathrm{~m}$ electrode spacing and by two real 3-D ERT grids with dimensions from $35 \times 35$ to $35 \times 125 \mathrm{~m}$ and $5 \times 5 \mathrm{~m}$ electrode spacing. The Dipole-Dipole electrode array was chosen on the grounds of its higher depth range and due to its sensitivity to vertical structures. Later, different profiles with Wenner-Schlumberger configuration were performed, namely, due to its stronger resistance to the geoelectrical noise. The effective depth range of this array is thus also rather higher, and the array is sensitive to both vertical and horizontal structures. Unfortunately, the profiles obtained by different methods can hardly be compared.

The 2-D data were processed with Res2Dinv software (Geotomo Software) with the use of finiteelement optimization and a default dumping factor. The RMS error cut-off of the modelled data was set to 
a maximum $60 \%$, whereas the maximum RMS error of the whole inverse model was $13.8 \%$, which can be considered as a reliable result under the conditions of the flysch bedrock. The topography was involved within the inversion process.

The real 3-D measurements were processed in the Res3Dinv software (Geotomo Software) and visualized in Surfer (Golden Software). Default inversion parameters and optimizations were used. The final 3-D inverse resistivity models (pseudoblocks) are displayed as horizontal slices as well as vertical sections in both the $\mathrm{x}$-axis and $\mathrm{y}$-axis directions.

\section{Radiocarbon dating}

In the New Part of the cave, several positions with small soda-straw-like stalactites have been recorded. Two samples were collected in order to obtain the minimum age of the cave. Sample C1 (length $5 \mathrm{~cm}$, width $\sim 1 \mathrm{~cm}$ ) was collected from the group of stalactites in the Chamber with Stalactites, as localized on Fig. 3. Sample C2 (length $6 \mathrm{~cm}$, width $\sim 1 \mathrm{~cm}$ ) was taken from the Mammoth Passage in the New Part (Fig. 3). At first, SEM images were obtained with the help of the scanning electron microscope Zeiss Supra 35 equipped with an energy dispersive X-ray spectrometer (EDS) produced by EDAX. SEM and EDS analyses were performed in the Laboratory of Engineering Materials and Biomaterials Research of the Silesian University of Technology, Gliwice, Poland. All the EDS analyses were qualitative only. The speleothems were subsampled to find layers containing calcite, based on the SEM results.

Radiocarbon dating of one sample (C1 - GdA-5458), was performed in the Gliwice Radiocarbon Laboratory (Poland). The sample was prepared according to the protocol reported by Piotrowska (2013). The surface of the calcite crystals was dissolved in $0.5 \mathrm{M} \mathrm{HCl}$, then the residue was rinsed with demineralized water and dried in $65^{\circ} \mathrm{C}$. The carbonate was reacted in a vacuum line with concentrated $\mathrm{H}_{3} \mathrm{PO}_{4}$. The evolved $\mathrm{CO}_{2}$ was separated cryogenically and transferred to a graphitization unit. The automated AGE equipment was used (Wacker et al., 2010). The measurement of the ${ }^{14} \mathrm{C}$ concentration was performed with use of the AMS technique by DirectAMS, Bothell, USA (Zoppi, 2010).

\section{RESULTS}

\section{Structural setting}

In several parts of the cave, there is a lack of data due to the intensive gravitational rotation of rock blocks, the talus-type character of the cave or the unrepresentative character of the cave morphology. With the exception of such parts, the structural measurement and its interpretation were carried out across the entire cave. Since the genesis and further development of the cave is directly connected with gravitational processes, practically all measured values are partly influenced by gravity-driven translations and rotations. The results of structural measurement and analysis are shown in the structural scheme of the Cyrilka Cave in Fig. 4A.
The primary layered rock structure is characterized by NNE- to ENE-strike bedding planes dipping solely towards ESE to SSE and points to a general WNW- to NNW-oriented vergence (Fig. 4B).

An analysis of all measured fractures revealed a clear structural pattern of mostly NNE-striking fractures steeply dipping to WNW. The NNE direction represents the most distinct strike of the extensional fractures varying from $\mathrm{N}$ to $\mathrm{NE}$ (Fig. 4C). Secondarily, perpendicular to the main subset, WNW-striking fissures are expressed within the cave structural model.

The shear fracture maxima are represented by $\mathrm{N}(\mathrm{NE})$-striking and by the less pronounced ENE- to E-striking directions (Fig. 4D). Almost solely NNEstriking dip-slip structures represent abundant and extensive brittle features observed in the cave. Strikeslip movements are characterized by ENE- and NNEstriking dextral shear fracture zones and NNW- to NNE-striking structures of a sinistral character.

These main fissure zones are interconnected by dextral shear fracture zones-the ENE-striking righthanded strike-slip system linking fissures in the New Part of the cave (DP34, DP39, DP42, DP66 in Fig. 4A) and the ENE-striking dextral zone in the Old Part of the cave (DP2, DP14, DP72, DP73). The left-handed and fissure interconnections are more abundant but of a smaller spatial extent-the sinistral fracture linking in the Back Part (DP23, DP28), the sinistral zone in the New Part (DP54) and the fissure interconnection in several parts of the cave (DP4, DP8, DP18, DP49).

\section{Electrical resistivity tomography survey}

Based on the measured ERT profiles (Figs. 5 and 6), the results can be divided into the following parts: (i) investigations of the internal structures of the DSL with the Cyrilka Cave and (ii) investigations of the vicinity of the known cave (upslope and north of the cave).

Figure 5 shows the six 2-D profiles. Profiles 1 and 2 were performed across the shallow terrain depression north of the known cave. A twometerthick layer of very high resistivities $(\sim 8,500 \mathrm{ohm}-\mathrm{m})$ indicates the weathered mantle. The lower sections in both profiles exhibit much lower resistivities ( 300-1,000 ohm-m). However, there is one exception in the central parts of both resistivity models just below the shallow terrain depression, where the zone of low resistivities extends up to the surface.

Profiles 3, 4, and 5 were performed almost perpendicular to the main direction of the landslide headscarp, as well as to the direction of underground passages following the NNE-striking system of mainly extensional fractures. The highest resistivity values appear within the upper $2.5 \mathrm{~m}$ in all three profiles ( 3,000-8,000 ohm-m). The deeper zones are characterized by significantly lower resistivities ( 300-1,000 ohm-m). Different resistivities are visible within the area of the landslide headscarp and below it. Several transitions between high- and low-resistivity zones indicate the intensive disruption of the massif which corresponds to the location of the Cyrilka Cave $(\sim 2,000 \mathrm{ohm}-\mathrm{m} / \sim 10 \mathrm{ohm}-\mathrm{m})$. Moreover, the depths 


\section{A Map scheme}
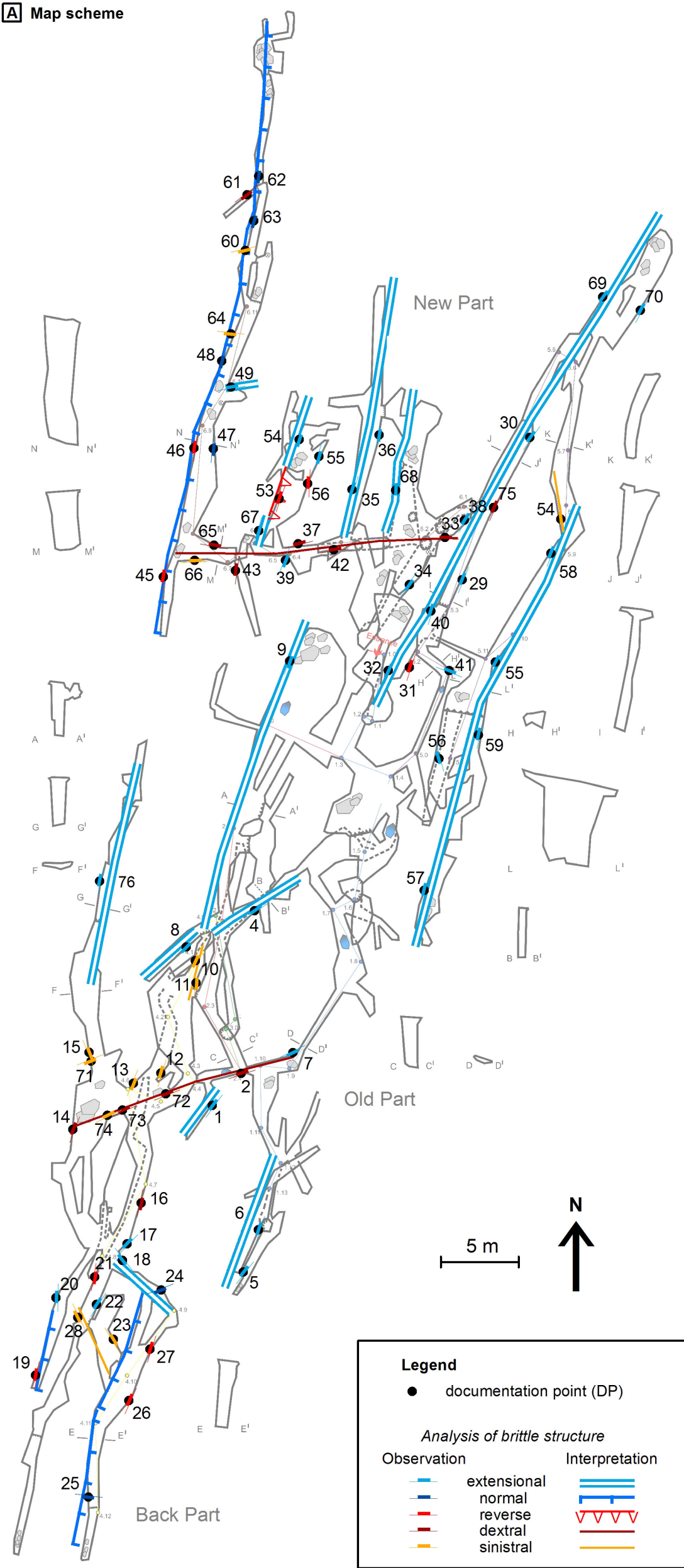

回 Bedding

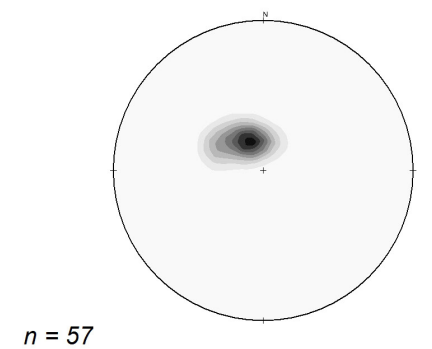

$n=57$

\section{Fractures}
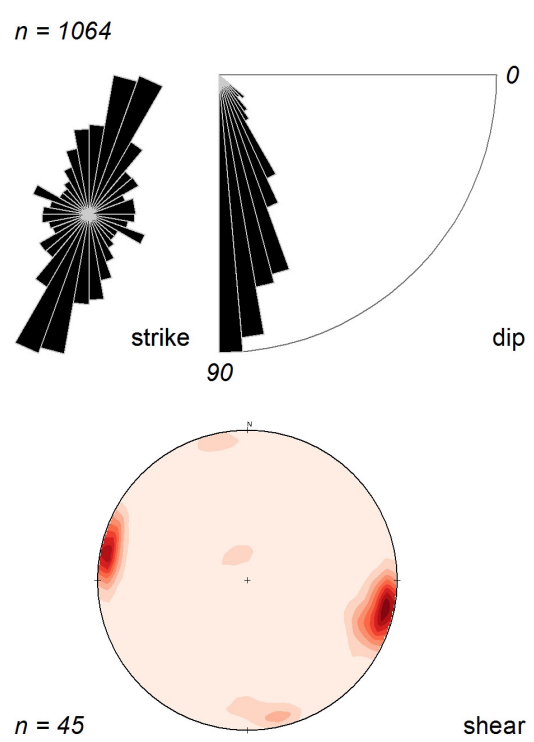

$n=51$

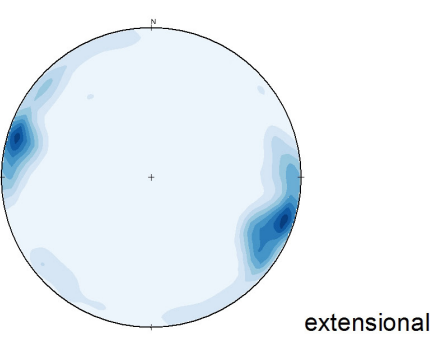

D Kinematics
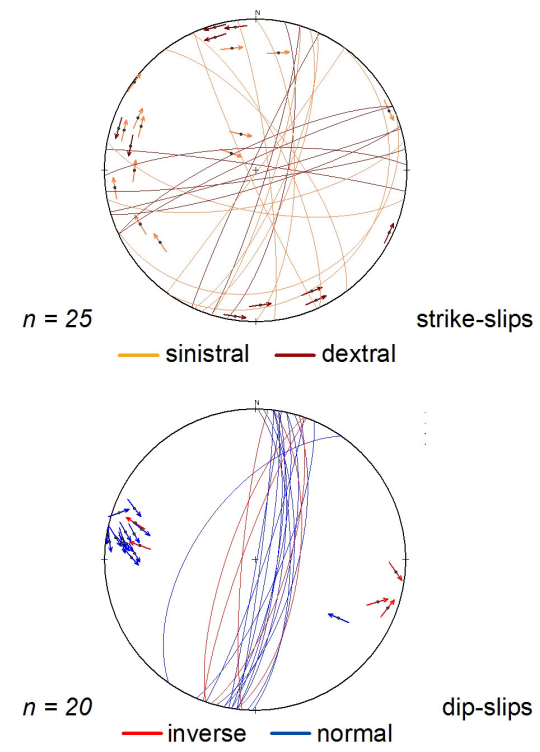

dip-slips

Fig. 4. Structural scheme of the Cyrilka Cave: A) Map scheme of cave tectonic control; B) Analysis of bedding planes; C) Fracture analysis; D) Kinematic analysis of fault slip data; plotted in Lambert equal area lower hemisphere projections; Fisher's method of contour density distribution (Fisher, 1953); $\mathrm{n}$ - number of measurements; cave plan by Lenart (2012). 
of the transition zones $(10-15 \mathrm{~m})$ also meet with the depths of the cave passages. The high-resistivity zones are further widespread below the landslide body (below the trench and further within the displaced rock blocks, $\sim 6,000$ ohm-m). The slope disruption below the headscarp line is the most visible on profile 5. Moreover, on profiles 3, 4, and 5, the isolated highresistivity zones with a short transition into low- resistivity zones are located below the slope which is situated above the existing landslide headscarp.

Profile 8 was significantly longer than the previous ones, and the electrode spacing was higher, which led to the lower resolution through the profile. Nevertheless, the vertical zone of low resistivity extending up to the surface is again visible at approximately $110 \mathrm{~m}$ of the profile.

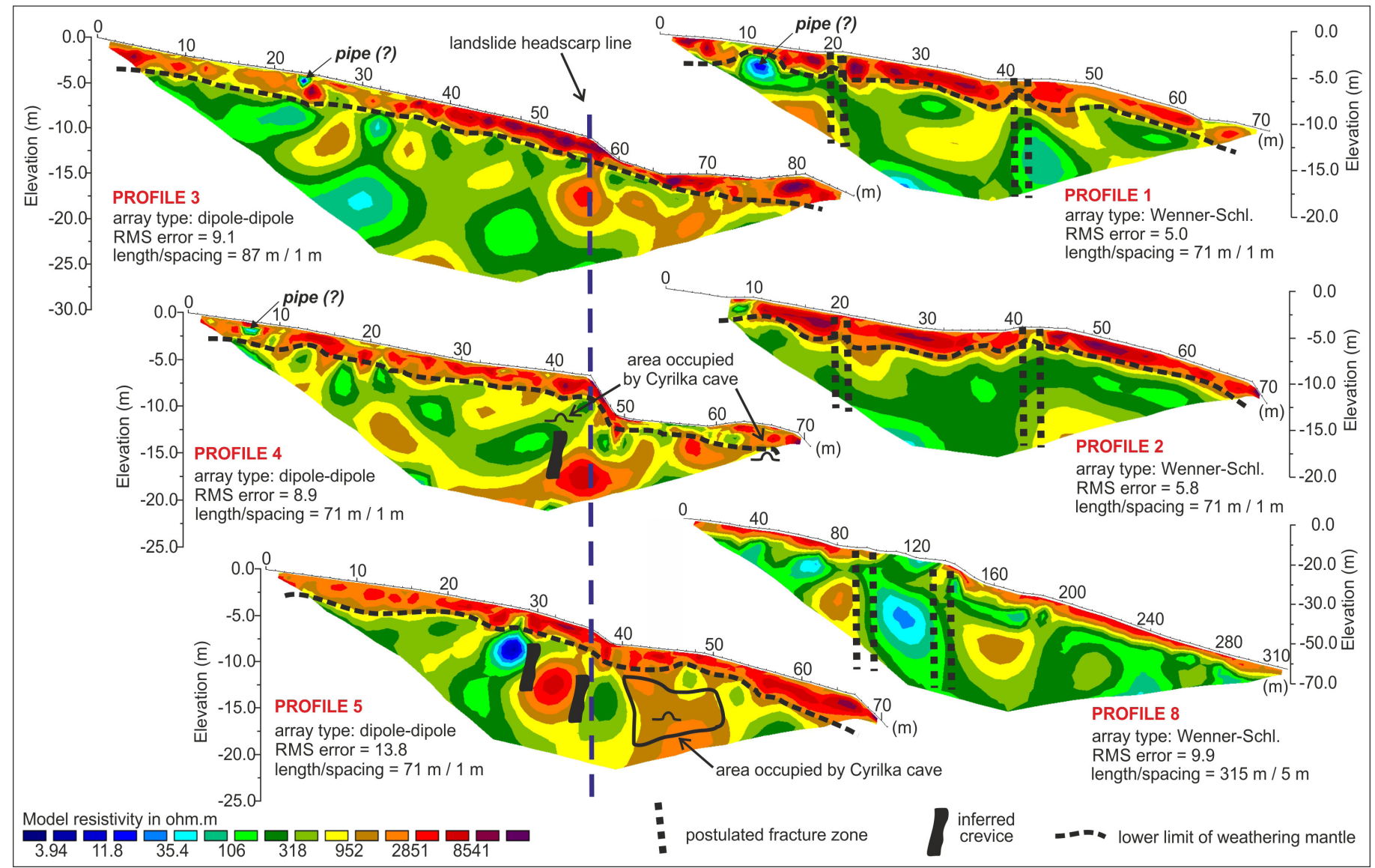

Fig. 5. Results of 2-D ERT measurements. Orientation of the profiles is marked in Fig. 1.

Concerning the 3-D ERT measurements, we performed two 3-D grids (6 and 7), undertaken above the Cyrilka Cave and its surroundings (Fig. 6). The results of the smaller grid 6 show the horizontal depth slices as well as the vertical slices in the form of cross sections and longitudinal sections. The horizontal depth slices reveal three parallel discontinuous zones of high resistivities ( 2,000 ohm-m) located 3-10 m below the surface, separated by low resistivities. In the $10 \mathrm{~m}$ depth, these transitions fade away and the lower resistivities prevail. Note that stripes of lower resistivities ( 300 ohm-m) within the uppermost slice change into stripes of high resistivities within the deeper slices. The vertical longitudinal sections (X-Z and $\mathrm{Y}-Z$ planes) then show a distinct contrast between high and low resistivities between 8-10 m. Unfortunately, the measurement was affected by a 19.1\% RMS error.

The results of the 3-D ERT grid 7 reveal slightly different features. The northern part of the profile, without any known caves, is represented by very high resistivities within the uppermost depth slices. In contrast, the middle part of the profile exhibits low resistivity. Between the depths of 4 and $6 \mathrm{~m}$ (below $2 \mathrm{~m}$, alternatively), relatively chaotic transitions between resistivities occur. Transition zones are then poorly visible below a depth of $6 \mathrm{~m}$.

The southern part, which captured the known passages of the Cyrilka Cave, is represented by high resistivities within the upper depth slices, but also by resistivity transitions at greater depth.

\section{A 19.9 ka old stalactite}

SEM images and corresponding EDS analyses were obtained separately for the $\mathrm{C} 1$ and $\mathrm{C} 2$ samples to decide the proper radiocarbon dating strategy for both speleothems. The core of the $\mathrm{C} 1$ speleothem consists of a $\mathrm{Ca}$ containing mineral, presumably $\mathrm{CaCO}_{3}$ (Fig. 7A). The outer shell of the $\mathrm{C} 1$ sample is built of many different minerals containing $\mathrm{Ca}, \mathrm{K}, \mathrm{Al}, \mathrm{Si}$, $\mathrm{Mg}$ and $\mathrm{Fe}$ elements (Fig. 7B). The EDS analyses for the $\mathrm{C} 2$ sample revealed that layers of the speleothem are built of aluminium and oxygen or silica- and oxygencontaining chemical compounds (Fig. 7C, D), probably $\mathrm{Al}_{2} \mathrm{O}_{3}$ and $\mathrm{SiO}_{2}$. The outermost carbonate part of the $\mathrm{C} 1$ sample core was selected as the most appropriate for radiocarbon dating.

The obtained ${ }^{14} \mathrm{C}$ age of the $\mathrm{C} 1$ sample was 17,610 $\pm 60 \mathrm{BP}$. This age was likely affected by the presence of dead carbon, whose proportion was impossible to 


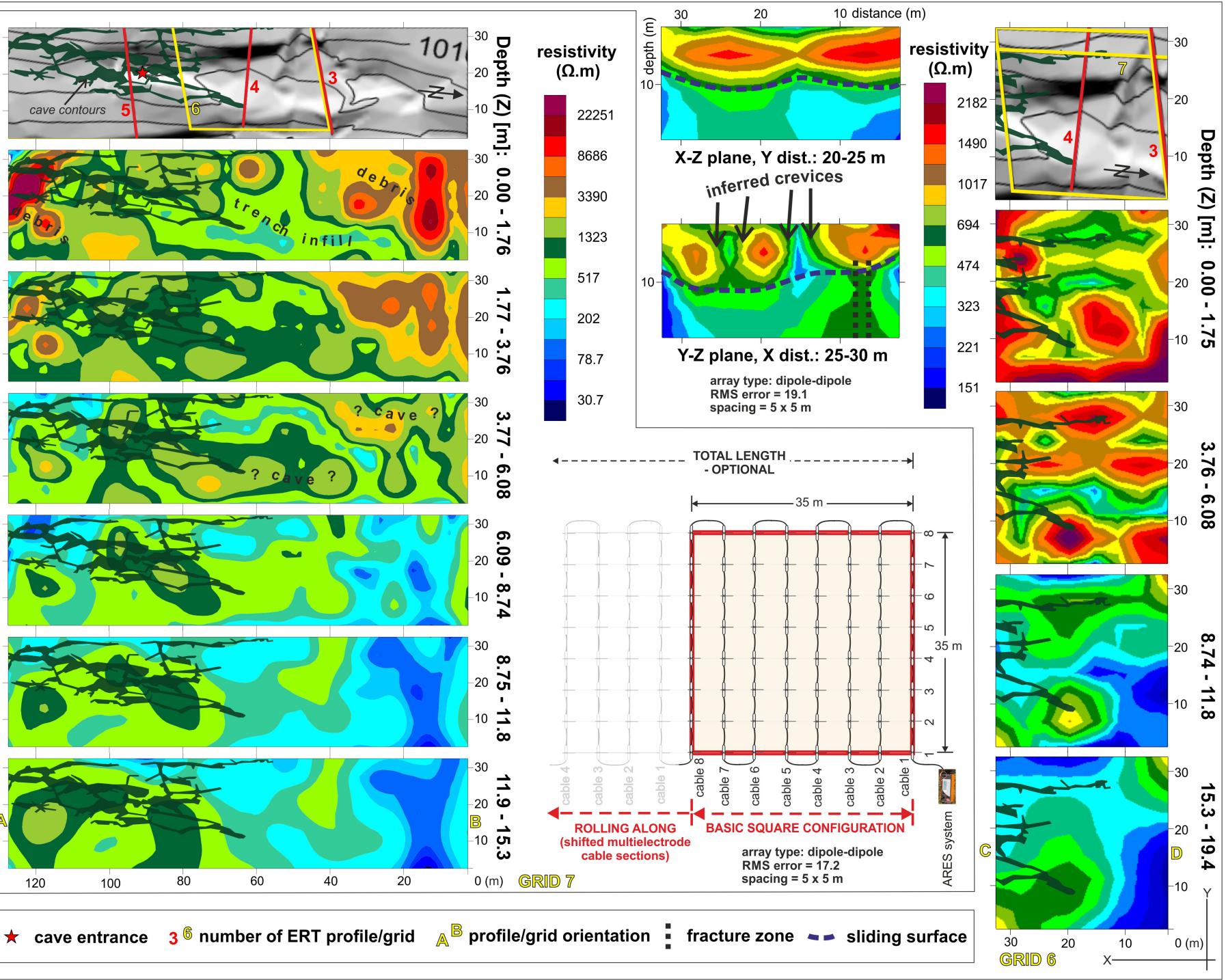

Fig. 6. Results of 3-D ERT measurements. Orientation of the profiles is marked in Fig. 1.

assign based on the presented data. However, Urban et al. (2015) reported a review and an extensive dataset for the Polish Outer Carpathian non-karst caves, and, following their paper, the dead carbon proportion (DCP) of $15 \%$ was used. Correspondingly, we assumed that the true ${ }^{14} \mathrm{C}$ age of the speleothem was $1,350 \pm 250$ years younger. This correction was applied, and the result was calibrated using the IntCal13 curve (Reimer et al., 2013) and the OxCal v.4.3 software (Bronk Ramsey, 2009). The calibrated age was $19.90 \pm 0.28 \mathrm{ka} \mathrm{BP}$.

\section{DISCUSSION}

\section{Tectonic control of cave development}

In the area of the Western Carpathians, studies dealing with the tectonic control of cave environments have been provided by Margielewski and Urban (2003), Pánek et al. (2010), Briestenský et al. (2011), Lenart et al. (2014), Szczygiel et al. (2015) or Littva et al. (2015). Some of these studies have linked tectonic models with crack displacement monitoring assessing contemporaneous slope deformation activity (Klimeš et al., 2012; Stemberk et al., 2017). Although a brief tectonic model of the Cyrilka Cave has already been made by Lenart et al. (2014) and Lenart (2015), these studies do not cover the detailed structural analysis.
In a thrust-related structural setting, we may expect two basic types of extensional fractures, both dipping normal to bedding. The first joint set (J1) is usually parallel to the bedding strike, and the second joint set (J2) strikes perpendicular to this direction (Price, 1966; Ramsay \& Huber, 1987). In the Cyrilka Cave, the NNE-striking extensional fractures have proved to be the most distinct joint set. Based on the structural position and the bedding character, this set has been regarded as a $\mathrm{J} 1$ joint set in the case of the tectonic origin of extensional structures.

The general tectonic model of the Cyrilka Cave is characterized by a system of NNE-striking extensional fractures interconnected by two distinct approximately E-striking dextral fracture zones. More abundant but less spatially extended, sinistral structures are oriented between NNE to ENE directions. Dip-slips represent mostly NNE-strike normal structures.

Due to gravitationally induced translations and rotations of rock blocks within the cave, kinematic data have not been used for paleostress analysis. Moreover, the mutual time scheme of possible deformation events would be hard to assess because of rare or even missing cross-cutting relations on fracture surfaces. However, predominantly subsidiary fractures of R and PT type were identified on fracture surfaces as kinematic indicators. As experimental data 

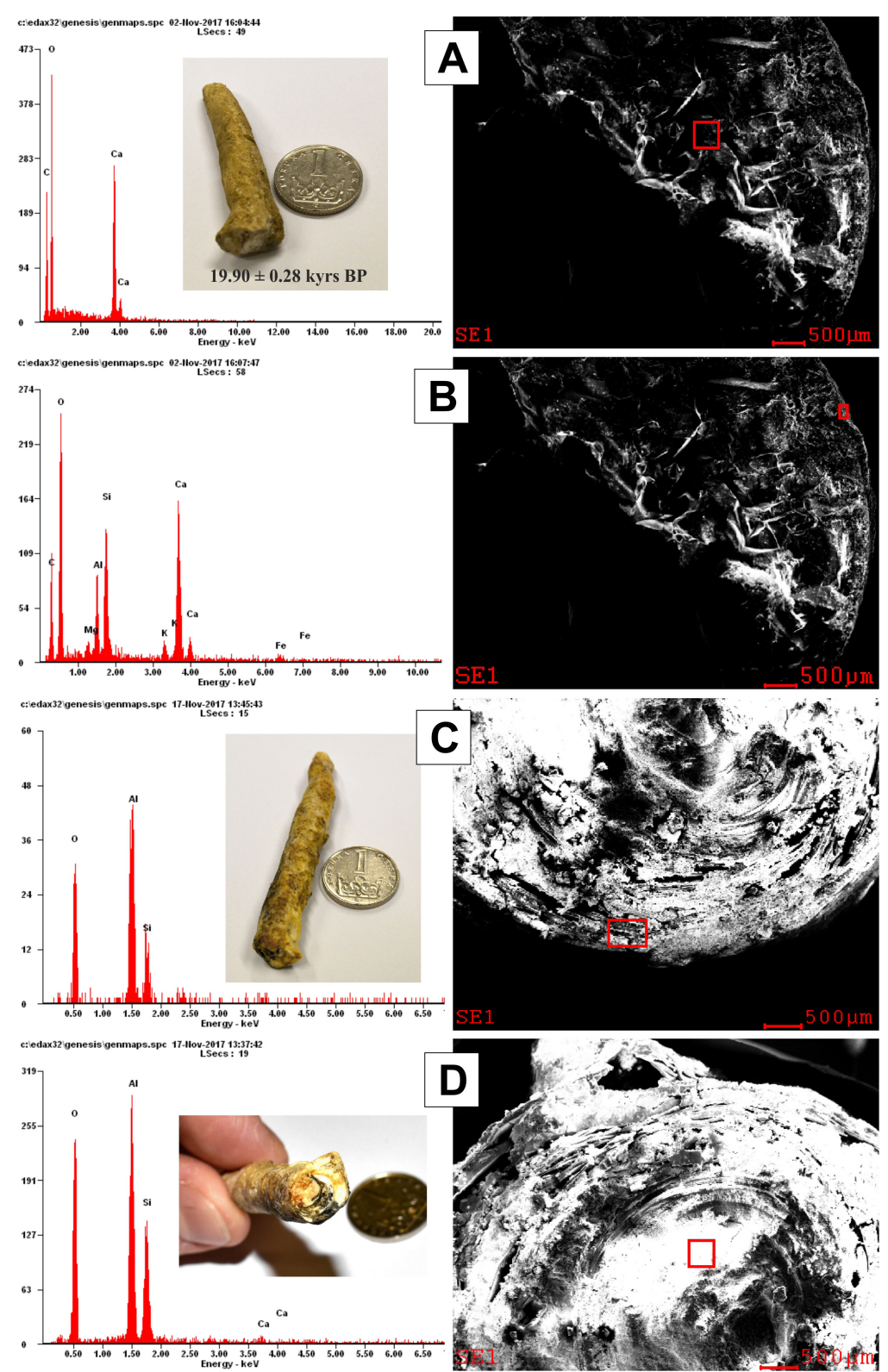

Fig. 7. EDS analysis and SEM images of stalactite samples: A) The outer layer of the core of the C1 sample; B) The outer layer of the C1 sample; C) The outer layer of the C2 sample; D) The core layer of the C2 sample; qualitative EDS spectrum on the graph equals an average for the area marked with red rectangle on the SEM image, photos of samples by J. Lenart.

show, R0 and PT type of minor fractures are formed exclusively in intact rocks (Petit, 1987). Therefore, the simultaneous exertion of the variable stress field is supposed to be a more likely scenario than an alternation of different reactivation phases during the formation of the specific structure of the rock massif. This assumption is additionally supported by a similar freshness and degree of weathering of most of the fractures assessed by approximate comparative observation. Nevertheless, within the cave, it is possible to observe also certainly younger structures (Fig. 8) than those discussed above. As inferred from the offset markers and geometry of the cave passages, the later gravitational opening of many passages took place by slip movements in the opposite directions compared to conditions under which the pre-existing brittle structure of the massif had been created. These reactivations resulted in the present failure structure, characterized by distinct propagation of contemporaneous sinistral movements within the slope deformation, which is in concert with findings introduced by Klimeš et al. (2012).

\section{Geomorphic evolution within the slope}

As the rock layers are inclined $9^{\circ}-35^{\circ}$ to the SE or SSE within the Cyrilka Cave site (Baroñ and Kašperáková, 2007; Malinčíková, 2013; Lenart et al., 2014), in conformity with the slope dip, the rigid beds are prone to the subsequent, or even consequent, translational movement along the plastic shale layers. The origin of several chambers within the cave or even of the whole gravitational deformation (e.g., Baroň and Kašperáková, 2007) is usually explained by these processes (e.g., Bedding Chamber in the Back Part or Chamber with Stalactites in the New Part). However, we speculate that some chambers remained as a free space after the vertical collapse of beds into a gravitationally relaxed space, not after the widening of the walls. Except for the talustype part near the entrance, the rest of the cave system is strictly a crevice-type. The origin of particular segments and their organization are explained in Lenart et al. (2014).

The crevice-type caves are often predisposed by the fracture zones/faults (Margielewski \& Urban, 2003; Lenart et al., 2014). Two previously identified fractures trending $\mathrm{E}-\mathrm{W}$ and ENE-WSW divide the cave into three morphologically different segments (Lenart et al., 2014; Fig. 3). However, concerning the tectonic predisposition of the whole system, the most pronounced is the NNE-SSW direction. Looking at the map of the cave (Fig. 3), the western passage is remarkably straight, as it is the border crevice between the relaxed slope with cave crevices and the undisturbed massif above it.

Further consequences are visible in the LIDAR data (Fig. 1B), where we clearly see that the fracture zone identified within the cave manifests itself north and south from the cave site by several trenches and linear depressions.

Based especially on the field experience from flysch environment (Pánek et al., 2011a; Tábořík et al.,

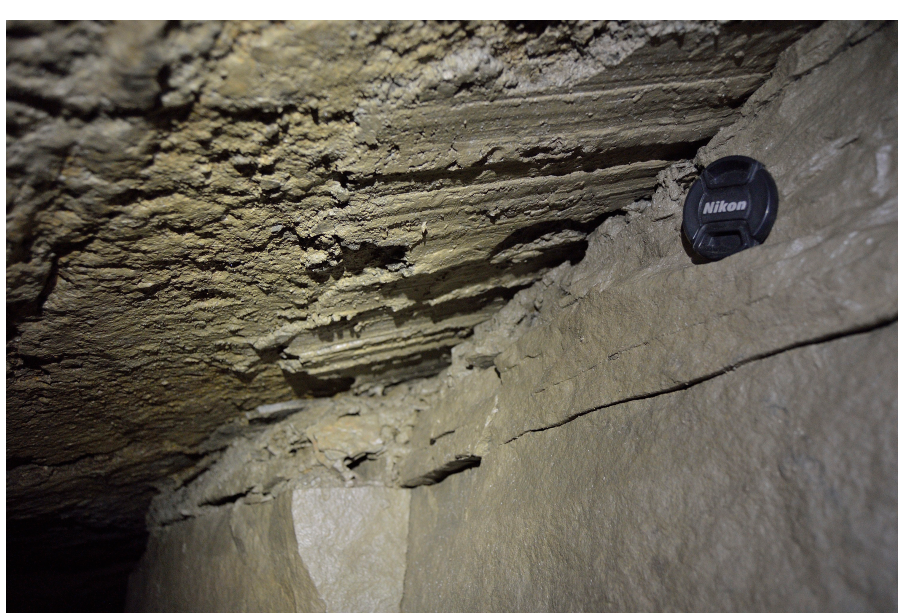

Fig. 8. Fresh striations imprinted in clayey mud on the ceiling as an evidence of recent gravitational movement (photo by M. Kašing). 
2017; and others), we have attempted to interpret and discuss the results of ERT measurements (Figs. 5 and 6):

(I) All profiles exhibit relatively low resistivities in their lower sections, which probably indicates undisturbed or only slightly disturbed flysch bedrock.

(II) Where the zone of low resistivities extends up to the surface (profiles 1,2, and 8), the presence of a water-saturated or highly disrupted fracture zone (fault zone) is probably indicated. This might be a continuation of the fracture zone recorded within the cave (Fig. 4A). This zone is also represented by the superficial displays. The related terrain forms a shallow elongated depression (Fig. 1C).

(III) The same feature is probably connected with the continuation of the line of the landslide headscarp (Fig. 1C).

(IV) However, the low resistivities indicate the existence of a fracture/fault without the opening of crevice-type caves. This is in contrast with the other ERT profiles, which exhibit transition zones between high and low resistivities representing the response of a free space filled with air within the crevices (Figs. 5 and 6), as reported by Tábořik et al. (2017). These crevices are in some places organized very close to each other and are seen in the ERT profiles as larger high-resistivity zones (mainly profile 5). We do not identify each specific crevice.

(V) Profiles 3, 4, 5, 6, and 7 exhibit the highest resistivity values within the upper layer. This is a reflection of blocky colluvium (very well expressed within the terrain by debris or even huge boulders above the cave), which is interrupted only at the bottom of the trench by the water-saturated finer colluvium. This is the effect of the subsequent deposition of the fine material below the landslide headscarp.

(VI) The rapid transitions between the low and high resistivities, chiefly on profiles 5,6 and 7 , could indicate underground crevices or even cave corridors, on the 3-D grid 6 depth slice ( $\mathrm{Y}-\mathrm{Z}$ plane) arranged in parallel. The transition zones correspond to the superficial configuration of the landslide terrain. They are located below the ground surface trench and below the headscarp.

(VII) Looking at profile 5, one of the transition domains is situated below the ground surface, upslope of the existing headscarp. This finding could not only indicate caves that are unknown so far but it also reveals the gravitational relaxation of the flysch massif behind the recent headscarp and mainly behind the detected fracture zone. This result could indicate a retrogressive gravitational evolution of the slope behind the fracture zone, which originally predisposed the slope failure (Lenart et al., 2014).

(VIII) On 3-D grids 6 and 7, the stripes of lower resistivities ( 300 ohm-m) within the uppermost slices change into stripes of high resistivities within the deeper slices, which can be explained by the subsidence of rocks (debris, boulders) above the underground passages (high resistivities $\sim 2,000$ ohm-m) and subsequently by the subsidence of the terrain above it. The formed depressions are then filled by fine sediment saturated with water (low resistivities).
(IX) The vertical longitudinal section of grid 6 (X-Z and $Y-Z$ planes) then demonstrates the depth of the disturbance within the slope, practically revealing the depth of the sliding surface as between 8-10 m (distinct contrast between high and low resistivities). Because the maximum depth of the cave is $16 \mathrm{~m}$ and the crevices are opened shallow below the surface, we do not expect more deeply situated accessible crevices.

(X) Although 3-D grids 6 and 7 both overlap each other, their results are relatively difficult to compare. More relevant seems to be the smaller 3-D grid 6, because the results obtained from it compare well with 2-D profiles 3 and 4 . Most likely, due to an electrode spacing of $5 \mathrm{~m}$ (more than the mean width of passages/crevices), the cave is not recognized satisfactorily on 3-D grids.

Both the 2-D and 3-D ERT methods revealed a similar geophysical image of the subsurface environment, but we did not compare the results in deep detail, which would require far more extensive analysis and testing.

Although some results of the ERT measurements suggest a retrogressive gravitational evolution of the slope behind the main fracture zone, the actual movements between particular rock blocks are complex, various and difficult to predict. According to the movements within one of the crevices, recently measured values indicate a very slow closing (0.2 mm/ 10 years) of the cave passage (Klimeš et al., 2012). Additionally, Foldyna (1968) described the complicated movements of rock blocks based on a comparison of cave maps. We assume complex and hardly determinable movements of particular blocks within the whole DSL.

\section{Cave genesis and age}

Although Tučník (1953) published the first accurate map of the cave and its detailed description, he did not propose any conclusions about the genesis of the cave. The first person who connected the development of this type of cave with mass movements was Novosad (1956). However, he emphasized the role of periglacial frost weathering during the Pleistocene cold stages in the cave's development. Kunsky (1957) considered similar caves to be relaxed space after great ice wedges. Additionally, Demek (1963) explained the genesis of such caves based strictly on the development of ice wedges during the cold periods. Foldyna (1968) also adopted this explanation and defined the following three-stage development of the caves: (i) tectonic jointing of the massif, (ii) development of the ice wedges under the periglacial climate and (iii) continuation of the relaxation of the massif during the humid Holocene. These three stages were further elaborated on by Wagner et al. (1990), who proposed that the jointing occurred during the Tertiary, whilst the ice wedges developed from the youngest Pliocene through the entire Pleistocene. Other than the role of the ice wedges, Wagner et al. (1990) also published a theory about ice lenses between the sedimentary layers, which acted as a sliding surface. They also admitted the influence of gravitational movements of the rocks, which are predisposed by the existence of thin plastic layers of shales. They considered the plastic 
deformation of the shales to be caused by changes in their consistency during the permafrost melting. The third phase is represented by the Holocene shaping of the caves, i.e., (i) mechanical weathering, (ii) slope processes (creep) and (iii) anthropogenic influences.

Since the 1990s, there has been a significant change in the understanding of the crevice-type cave genesis and researchers specifically focused on the gravitational origin of these caves (Baroñ et al., 2003; Margielewski \& Urban, 2003, 2017; Klimeš et al., 2012; Lenart et al., 2014). These authors postulated the development of crevice-type caves during the humid phases of the Holocene. Minimum ages were obtained from small stalactites from the crevice-type caves in the Polish Carpathians using radiocarbon and U/ Th-series dating and palynology (Urban et al., 2015) and correspond to the Early Preboreal, the BorealAtlantic transition, the Atlantic Phase, the Early Subboreal, the Subboreal-Subatlantic transition and the $11^{\text {th }}$ century (after Starkel, 1977; Margielewski, 2003, 2006; Margielewski et al., 2010). Although the calibrated age $19.90 \pm 0.28 \mathrm{ka}$ BP obtained from the Cyrilka Cave is the oldest age detected in the area of the Outer Flysch Carpathians so far, some crevicetype caves in the United Kingdom have been dated by U-series to over $350 \mathrm{ka}$ (Farrant et al., 2015).

When we assume that the speleothem dated from the Cyrilka Cave could only grow after the gravitational release of the underground space, the obtained age should be counted as the minimum age of the cave. However, on the other hand, the dead carbon stored for a long time in the calcareous cement of the rock can shift the obtained age more to the past and the real age of the speleothem would be lower. According to the dating strategy, the obtained age is equal to the maximum age of the speleothem. To resolve the discrepancy between the maximum age of the speleothem and the minimum age of the cave, we should further consider the indirect evidence pointing to the cave's age.

Because the origin of the cave is linked to the development of the DSL, we can use ages from dated landslides from the flysch of the Outer Carpathians to estimate the ages of related crevice-type caves. The ${ }^{14} \mathrm{C}$ data of dozens of landslides from the Polish, Czech and Slovak Outer Flysch Carpathians mostly reveal ages belonging to the humid Holocene phases (Margielewski, 2003, 2006; Pánek et al., 2011a, 2013). However, are these ages appropriate for landslide formation? The ages are mostly obtained from organic material (wood, needles, detritus, leaves or organic mud) in peat bogs, trench infills or landslidedammed lakes. We do not know whether this material could have been redeposited later. Although Pánek (2015) accepts this dating approach as reliable, it is still only the minimum age that is revealed by this method, which may often detect only a reactivation of the landslide instead of the true age of the original landslide event. Moreover, data obtained from speleothems reveal minimum ages only.

When we consider the possible chronic evolution of landslides with reactivations (Pánek et al., 2011b, 2013) and the development of crevice-type caves mostly within the upper parts of landslides, especially near the headscarps or even above them (Lenart et al., 2014; Margielewski \& Urban, 2003), we arrive at the conclusion that the age of the landslide formation, especially the headscarp area with caves, could be much higher than the minimum ages obtained from peat bogs, trench infills or landslide-dammed lakes. Conversely, crevice-type caves could be younger due to the gradual gravitational opening of crevices above the older headscarp.

When discussing the Cyrilka Cave age, we must take into account the latest investigations:

(i) Urban et al. (2015) dated speleothems from similar caves in Poland. The oldest growth of aragonite flowstone occurred in the Upper Vistulian (Upper Pleniglacial; $16 \mathrm{ka}{ }^{14} \mathrm{C}$ cal BP after DCP correction). They believe that most of the caves were formed at the end of the Pleistocene or Early Holocene and that their growth continued throughout the Holocene, which is documented by 32 dated samples. We believe that the caves must have been formed some time before the establishment of the speleothems, especially in the case of the stalactites and stalagmites. Flowstones on the walls could have grown together with the gravitational widening of the crevices. However, the stalactites or stalagmites situated some distance from the marginal walls must have risen into an underground space previously released by a slow or sudden opening or even by the collapsing of the underlying rocks. Unfortunately, the authors do not report the exact position of dated speleothems. The $19.90 \pm 0.28 \mathrm{ka} \mathrm{BP}$ old stalactite from the Cyrilka Cave grew from the ceiling of the Chamber with Stalactites. We suppose that the chamber originated from both the ongoing gravitational spreading and collapsing. It is practically impossible to decide which process formed the space for the growth of speleothems in the first place.

(ii) Pánek et al. (2014) documented large landslides from the marginal slopes of the Outer Flysch Carpathians in Czechia. The ${ }^{14} \mathrm{C}$ ages belong to the humid Interpleniglacial of the Last Glacial ( 36 and 51-56 cal. ka BP). Again, the oldest age is obtained from the organic limnic peat, which overlaps another landslide diamicton. Thus, the original failure could again be older.

(iii) The finding of the troglophilous fly Crumomyia parentela alpicola (published by Roháček, 2014) in the entrance portion of the Cyrilka Cave could indirectly indicate the age of the cave. This subspecies is considered to be a glacial relict and exhibits several morphological adaptations (more reduced eyes, shorter wings) to the cavernicolous milieu compared with known populations (Roháček, 2014). The same author believes that these modifications were evolved due to a "long isolation of the population in the cave".

With respect to the gravitational origin of the cave, the minimum ages obtained from the speleothems deposited in the crevice-type caves, the possibility that landslides were already active during the Last Glacial only $17 \mathrm{~km}$ away and the recent existence of a troglophilous fly population which was isolated in the cave for a long time, we believe that the Cyrilka Cave 
could be older than previously assumed, possibly even of the Late Pleistocene age.

\section{CONCLUSIONS}

Although the Cyrilka Cave has been known for many years, it became an important focus of research during the last few years. The cave reveals specific conditions of a disrupted landslide body and plays a significant role as a source of knowledge regarding the predispositions, development and evolution of deepseated landslides and related crevice-type caves.

The structural analysis has extended the current knowledge about the morphological pattern of the cave and suggested a geometric and kinematic model illustrating a specific structure within the rock massif, which allowed the development of subsequent gravitational movements. Interrupted by a system of NNE-striking fissures interconnected by two continuous ENE-striking dextral fracture zones, the primary structure of the rock massif is characterized by NNE- to ENE-striking bedding planes. The propagation of recent sinistral strike-slips within the rock massif is a distinct structural feature within the cave.

There were several dozen metres of new passages discovered by cavers between 2010 and 2013, and the geophysical measurements revealed other sections with possible undiscovered underground passages. The same measurements showed the significance of the NNE-SSW-oriented fractured zone to the evolution of the cave. Some of the unknown crevices were probably revealed by ERT behind and upslope of the headscarp line. It could also reveal the retrograde evolution of the landslide. Methodologically, we first used the real 3-D ERT measurements in the incoherent sedimentary flysch rocks and proved its ability to capture the crevices and fracture zones.

The calibrated radiocarbon age of the outermost part of the carbonate stalactite core was $19.90 \pm 0.28$ ka BP as the oldest datum obtained from a crevicetype cave in the Outer Flysch Carpathians so far. Even though this number represents the minimum age of the cave formation, because of the dead carbon influence, it is also the maximum age of the analysed speleothem.

Based on a review of previous studies, including the latest results from the Outer Western Carpathians, we thoroughly discussed the problems related to the cave's age and evaluated the possibilities of the Late Pleistocene origin of the cave.

For its natural, scientific and historical importance, the authors recommend the protection of the cave and its surroundings as a national monument.

\section{ACKNOWLEDGEMENTS}

The research was co-funded by a financial subsidy from the Czech Science Foundation project 17$17712 \mathrm{~S}$, by the institutional support of the Center for Geosphere Dynamics (UNCE/SCI/006), by the support of the long-term conceptual development research organization RVO: 67985891, by the SGS SP2017/22 project of VŠB-Technical University of Ostrava and by the Silesian University of Technology internal grants BK-229/RIF/2017 and BKS-101/RIF/2017. The authors would like to thank American Journal Experts Editing Services and Markéta Gregorová for English style revision, , and two anonymous reviewers who provided useful comments.

\section{REFERENCES}

Baroň I. \& Kašperáková D., 2007 - Numerical analysis of Silesian nappe gravitational disintegration by means of FDM (Case study: Radhošt' - Pustevny). Zprávy o geologických výzkumech v roce, 2006: 49-52 (in Czech).

Baroň I., Cílek V. \& Melichar R., 2003 - Pseudokarst caves as an indicators of slope movements. Geologické výzkumy na Moravě a ve Slezsku v roce 2002: 84-87 (in Czech).

Bella P. \& Gaál L., 2013 - Genetic types of non-solution caves. In: Filippi M. \& Bosák P. (Eds.), Proceedings of the $16^{\text {th }}$ International Congress of speleology, Brno, 3: 237-242.

Briestenský M., Stemberk J. Michalik J., Bella P. \& Rowberry M., 2011 - The use of a karstic cave system in a study of active tectonics: fault movements recorded at Driny Cave, Malé Karpaty Mts. (Slovakia). Journal of Cave and Karst Studies, 73: 114-123. https://doi.org/10.4311/jcks2010es0166

Bronk Ramsey C., 2009 - Bayesian analysis of radiocarbon dates. Radiocarbon, 51 (1): 337-360. https://doi.org/10.1017/S0033822200033865

Demek J., 1963 - Caves in the flysch sandstones of the Moravian-Silesian Carpathians. Československý kras, 15:127-130 (in Czech).

Eliáš M., 2000 - Relation between Pústevny Sandstone and Malinouská skála Sandstone (Godula Formation s.s.) in the Beskydy Mts. Geologické výzkumy na Moravě a ve Slezsku v roce 1999: 64-66 (in Czech).

Farrant A.R., Noble S.R., Barron A.J.M., Self C.A. \& Grebby S.R., 2015 - Speleothem U-series constraints on scarp retreat rates and landscape evolution: an example from the Severn valley and Cotswold Hills gull-caves, UK. Journal of the Geological Society, 172: 63-76. https://doi.org/10.1144/jgs2014-028

Fisher R.A., 1953 - Dispersion on a sphere. Proceedings of the Royal Society of London A, 217: 295-305. https://doi.org/10.1098/rspa.1953.0064

Foldyna J., 1968 - Pseudokarst in the Godula beds of Godula rock formation (Moravian-Silesian Beskyds). Sborník vědeckych prací VŠB v Ostravě, řada hornickogeologická, 14: 83-103 (in Czech).

Griffiths D.H. \& Barker R.D., 1993 - Two-dimensional resistivity imaging and modelling in areas of complex geology. Journal of Applied Geophysics, 29: 211-226. https://doi.org/10.1016/0926-9851(93)90005-J

Imrich P., Kováčik M., Bóna J. \& Majerníčková F., 2007 - Geological control of the gravitational processes in the Spišská Hill pseudokarst region (Levočské vrchy Mts., Slovakia). Nature Conservation, 63: 47-55.

Klimeš J., Rowberry M.D., Blahůt J., Briestensky M., Hartvich F., Koštak B., Rybař J., Stemberk J. \& Štěpančiková P., 2012 - The monitoring of slow-moving landslides and assessment of stabilisation measures using an optical-mechanical crack gauge. Landslides, 9 (3): 407-415. https://doi.org/10.1007/s10346-011-0306-4

Konta J., 1967 - Use of monochloracetic acid for separation of insoluble residues from limestones and related rocks. Acta Universitatis Carolinae - Geologica, 4: 327-330. 
Kunský J., 1957 - Types of pseudokarst features in Czechoslovakia. Československý Kras, 10: 108-124 (in Czech).

Lenart J., 2012 - Dynamics of crevice-type caves microclimate in the Czech part of the Outer Western Carpathians (on examples of selected locations). Slovenský Kras, 50: 211-218 (in Czech).

Lenart J., 2015 - Morphological patterns of crevicetype caves in sedimentary rocks of the Outer Western Carpathians (Czech Republic). Journal of Cave and Karst Studies, 77: 165-176.

https://doi.org/10.4311/2014ES0113

Lenart J., Wagner J. \& Škarpich V., 2013 - Discoveries of crevice-type caves in the Carpathian flysch in years 1997-2012. Speleofórum, 32: 34-37 (in Czech).

Lenart J., Pánek T. \& Dušek R., 2014-Genesis, types and evolution of crevice-type caves in the Flysch Belt of the Western Carpathians (Czech republic). Geomorphology, 204: 459-476.

https://doi.org/10.1016/j.geomorph.2013.08.025

Littva J., Hók J. \& Bella P., 2015 - Cavitonics: using caves in active tectonic studies (Western Carpathians, case study). Journal of Structural Geology, 80: 47-56. https://doi.org/10.1016/j.jsg.2015.08.011

Loke M.H., 1999 - Electrical imaging surveys for environmental and engineering studies, A practical guide to 2-D and 3-D surveys.

http://www.geomatrix.co.uk/tools/applicationnotes/Lokenote.pdf [accessed: March 31, 2015].

Loke M.H. \& Barker R.D., 1996 - Rapid least-squares inversion of apparent resistivity pseudosections by a quasi-Newton method. Geophysical Prospecting, 44: 131-152.

https://doi.org/10.1111/j.1365-2478.1996.tb00142.x

Majerníčková F., Majerníčková G. \& Imrich P., 2005 The Levočské vrchy mountains - pseudokarst paradise. Bulletin of the Slovak Speleological Society, 2005: 36-42.

Malinčíková K., 2013 - Pseudokarst cave Cyrilka in the Morauskoslezské Beskydy Mountains. Unpublished Bachelor Thesis, Palacký University Olomouc, 58 p. (in Czech).

Malinčíková K., 2015 - Hydrochemic and petrochemic characteristic of the Cave Cyrilka in Morauskolezské Beskydy Mountains. Unpublished Master Thesis, Palacký University Olomouc, 73 p. (in Czech).

Margielewski W., 2003 - Late Glacial-Holocene paleoenvironmental changes in the Western Carpathians: case studies of landslide forms and deposits. Folia Quaternaria, 74: 1-97.

Margielewski W., 2006 - Records of the Late GlacialHolocene palaeoenvironmental changes in landslide forms and deposits of the Beskid Makowski and Beskid Wyspowy Mts. area (Polish Outer Carpathians). Folia Quaternaria, 76: 1-149.

Margielewski,W. \& Urban J., 2003 - Crevice-type caves as initial forms of rock landslide development in the Flysch Carpathians. Geomorphology, 54: 325-338. https://doi.org/10.1016/S0169-555X(02)00375-6

Margielewski W. \& Urban J., 2017 - Gravitationally induced non-karst caves: Tectonic and morphological constrains, classification, and dating; Polish Flysch Carpathians case study. Geomorphology, 296: 160-181. https://doi.org/10.1016/j.geomorph.2017.08.018

Margielewski W., Krapiec M., Valde-Nowak P. \& Zernitskaya V., 2010 - A Neolithic yew bow in the Polish Carpathians: Evidence of the impact of human activity on mountainous palaeoenvironment from the Kamiennik landslide peat bog. Catena, 80: 141-153.

https://doi.org/10.1016/j.catena.2009.11.001
Milsom J., 2005 - Field Geophysics, the Geological Field Guide Series. Wiley, 232 p.

Menčik E., Adamová M., Dvořák J., Dudek A., Jetel J., Jurková A., Hanzlikková E., Houša V., Peslová H., Rybářová L., Šmíd B., Šebesta J., Tyráček J. \& Vašíček Z., 1983 - Geology of the Moravskoslezské Beskydy Mts. and Podbeskydská pahorkatina highland. Ústřední Ústav Geologický, Praha, 304 p. (in Czech).

Novosad S., 1956 - The fosil breakup of the Lukšinec ridge near Lysa hora Mt. Časopis pro mineralogii a geologii, 1 (2): 126-131 (in Czech).

Pánek T., 2015 - Recent progress in landslide dating: a global overview. Progress in Physical Geography, 39: 168-198.

https://doi.org/10.1177/0309133314550671

Pánek T., Margielewski W., Tábořik P., Urban J., Hradecký J. \& Szura C., 2010 - Gravitationally induced caves and other discontinuities detected by $2 D$ electrical resistivity tomography: Case studies from the Polish Flysch Carpathians. Geomorphology, 123: 165-180. https://doi.org/10.1016/j.geomorph.2010.07.008

Pánek T., Tábořík P., Klimeš J., Komárková V., Hradecký J. \& Štastný M., 2011a - Deep-seated gravitational slope deformations in the highest parts of the Czech Flysch Carpathians: Evolutionary model based on kinematic analysis, electrical imaging and trenching. Geomorphology, 129: 92-112.

https://doi.org/10.1016/j.geomorph.2011.01.016

Pánek T., Šilhán K., Tábořík P., Hradecký J., Smolková V., Lenart J., Brázdil R., Kašičková L. \& Pazdur A., $2011 \mathrm{~b}$ - Catastrophic slope failure and its origins: Case of the May 2010 Girová Mountain long-runout rockslide (Czech Republic). Geomorphology, 130: 352-364. https://doi.org/10.1016/j.geomorph.2011.04.020

Pánek T., Smolková V., Hradecký J., Baroñ I. \& Šilhán K., 2013 - Holocene reactivations of catastrophic complex flow-like landslides in the Flysch Carpathians (Czech Republic/Slovakia). Quaternary Research, 80: 33-46. https://doi.org/10.1016/j.yqres.2013.03.009

Pánek T., Hartvich F., Jankovská V., Klimeš J., Tábořík P., Bubík M., Smolková V. \& Hradecký J., 2014 - Large Late Pleistocene landslides from the marginal slope of the Flysch Carpathians. Landslides, 11: 981-992.

https://doi.org/10.1007/s10346-013-0463-8

Petit J.P., 1987 - Criteria for the sense of movement on fault surfaces in brittle rocks. Journal of Structural Geology, 9: 597-608.

https://doi.org/10.1016/0191-8141(87)90145-3

Piotrowska N., 2013 - Status report of AMS sample preparation laboratory at GADAM Centre, Gliwice, Poland. Nuclear Instruments and Methods in Physics Research Section B, 294: 176-181.

https://doi.org/10.1016/j.nimb.2012.05.017

Price N.J., 1966 - Fault and Joint Development in Brittle and Semi-brittle Rocks. Pergamon, Oxford, 176 p.

Ramsay J.G. \& Huber M.I., 1987 - The Techniques of Modern Structural Geology, vol. 2: Folds and Fractures. Academic Press, London, p. 309-700.

Reimer P.J., Bard E., Bayliss A., Beck J.W., Blackwell P.G., Bronk Ramsey C., Grootes P.M., Guilderson T.P., Haflidason H., Hajdas I., Hatte C., Heaton T.J., Hoffmann D.L., Hogg A.G., Hughen K.A., Kaiser K.F., Kromer B., Manning S.W., Niu M., Reimer R.W., Richards D.A., Scott E.M., Southon J.R., Staff R.A., Turney C.S.M. \& van der Plicht J., 2013 - IntCal13 and Marine13 Radiocarbon Age Calibration Curves 0-50,000 Years cal BP. Radiocarbon, 55 (4): 1869-1887. https://doi.org/10.2458/azu js rc.55.16947 
Riedel W., 1929 - Zur Mechanik geologischer Brucherscheinungen. Centralblatt für Mineralogie, Abteilung B, 354-368 (in German).

Roháček J., 2014 - First cavernicolous population of Crumomyia parentela (Séguy, 1963) and a review of cave-dwelling fauna of Sphaeroceridae (Diptera) in the Czech Republic. Acta Musei Silesiae, Scientiae Naturales, 63: 97-109.

Starkel L., 1977 - Paleogeography of the Holocene. PWN, Warszawa, 363 p. (in Polish).

Stemberk J., Hartvich F., Blahůt J., Rybář \& J., Krejčí O., 2017 - Tectonic strain changes affecting the development of deep seated gravitational slope deformations in the Bohemian Massif and Outer Western Carpathians. Geomorphology, 289: 3-17.

https://doi.org/10.1016/j.geomorph.2016.07.004

Szczygiel J., Gaidzik K. \& Kicinska D., 2015 - Tectonic control of cave development: a case study of the Bystra Valley in The Tatra Mts., Poland. Annales Societatis Geologorum Poloniae, 85, 387-404. https://doi.org/10.14241/asgp.2015.015

Tábořik P., Lenart J., Blecha V., Vilhelm J. \& Turský O., 2017 - Geophysical anatomy of counter-slope scarps in sedimentary flysch rocks (Outer Western Caprathians). Geomorphology, 276: 59-70. https://doi.org/10.1016/j.geomorph.2016.09.038

Tučník D., 1953 - Caves of Radhošt' (Cracks on Pustevny and Radhošt' Mt.). Československý kras, 6: 185-186 (in Czech).

Urban J. \& Margielewski W., 2013 - Types of non-karst caves in Polish Outer Carpathians - historical review and perspectives. In: Filippi M. \& Bosák P., (Eds.), Proceedings of the $16^{\text {th }}$ International Congress of Speleology, 3: 314-319.

Urban J., Margielewski W., Schejbal-Chwastek M. \& Szura C., 2007a - Speleothems in some caves of the Beskidi Mts., Poland. Nature Conservation, 63: 109-117.
Urban J., Margielewski W., Žák K., Hercman H., Sujka G. \& Mleczek T., 2007b - The calcareous speleothems in the pseudokarst Jaskinia Słowianska-Drwali cave, Beskid Niski Mts., Poland. Nature Conservation, 63: 119-128.

Urban J., Margielewski W., Hercman H., Žák K., Zernitska V., Pawlak J. \& Schejbal-Chwastek M., 2015 - Dating of speleothems in non-karst caves methodological aspects and practical application, Polish Outer Carpathians case study. Zeitschrift für Geomorphologie, 59 (Suppl. 1): 185-210.

Vitek J., 1983 - Classification of pseudokarst forms in Czechoslovakia. International Journal of Speleology, 13: 1-18. https://doi.org/10.5038/1827-806X.13.1.1

Wacker L., Nemec M. \& Bourquin J., 2010-A revolutionary graphitisation system: Fully automated, compact and simple. Nuclear Instruments and Methods in Physics Research Section B, 268 (7-8): 931-934.

https://doi.org/10.1016/j.nimb.2009.10.067

Wagner J. \& Lenart J., 2012 - The half-kilometre-length of the Cyrilka cave exceeded. Speleoforum, 31: 53-57 (in Czech).

Wagner J., Demek J. \& Stráník Z., 1990 - Caves of the Morauskoslezské Beskydy Mts. and its surroundings. Knihovna České speleologické společnosti, Praha, 132 p. (in Czech).

Ward S.H., 1990 - Resistivity and induced polarization methods. In: Mailett G.M., Rizzo E., Revil A. \& Vella C., 2005 - High resolution electrical resistivity tomography (ERT) in a transition zone environment: Application for detailed internal architecture and infilling processes study of a Rhône River paleo-channel. Marine Geophysical Researches, 26: 317-328.

Zoppi U., 2010 - Radiocarbon AMS Data analysis: from measured isotopic ratios to ${ }^{14} \mathrm{C}$ concentrations. Radiocarbon, 52 (1): 165-170. https://doi.org/10.1017/S0033822200045112 